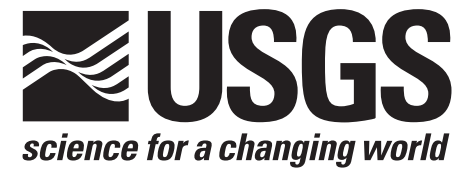

\title{
An Allocation of Undiscovered Oil and Gas Resources to Big South Fork National Recreation Area and Obed Wild and Scenic River, Kentucky and Tennessee
}

By Christopher J. Schenk, Timothy R. Klett, Ronald R. Charpentier, Troy A. Cook, and Richard M. Pollastro

Open-File Report 2006-1048

U.S. Department of the Interior

U.S. Geological Survey 


\section{U.S. Department of the Interior}

P. Lynn Scarlett, Acting Secretary

\section{U.S. Geological Survey \\ P. Patrick Leahy, Acting Director}

U.S. Geological Survey, Reston, Virginia: 2006

For product and ordering information:

World Wide Web: http://www.usgs.gov/pubprod

Telephone: 1-888-ASK-USGS

For more information on the USGS - the Federal source for science about the Earth, its natural and living resources,

natural hazards, and the environment:

World Wide Web: http://www.usgs.gov

Telephone:1-888-ASK-USGS

Any use of trade, product, or firm names is for descriptive purposes only and does not imply endorsement by the U.S. Government.

Although this report is in the public domain, permission must be secured from the individual copyright owners to

reproduce any copyrighted materials contained within this report.

Suggested citation:

Schenk, C.J, Klett, T.R., Charpentier, R.R., Cook, T.A., Pollastro, R.M., 2006, An Allocation of Undiscovered Oil and Gas Resources to Big South Fork National Recreation Area and Obed Wild and Scenic River, Kentucky and Tennessee: U.S. Geological Survey Open File Report 2006-1048, 7 p. 


\section{Contents}

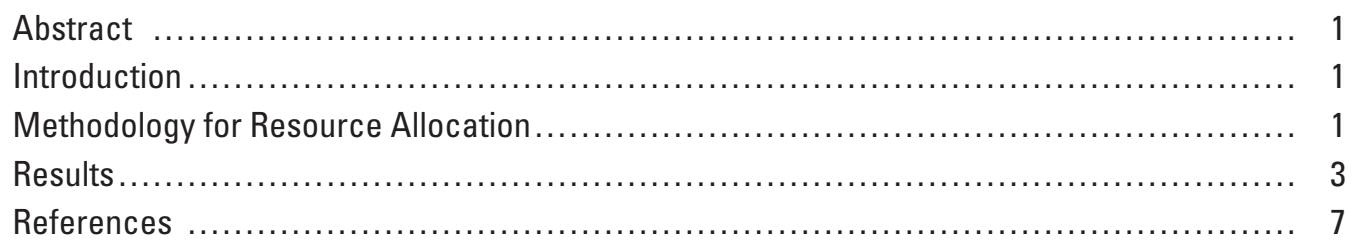

\section{Figures}

1. Map showing locations of Big South Fork National Recreation Area and Obed Wild and Scenic River in Kentucky and Tennessee

2. Map showing oil and gas wells and selected oil and gas fields in and around Big South Fork National Recreation Area, Kentucky and Tennessee ......................... 5

3. Map showing oil and gas wells and selected oil and gas fields in and around Obed Wild

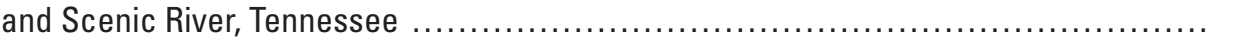

\section{Tables}

1. Acreages for those parts of assessment units (AU) and plays that lie within the Big South Fork National recreation Area (NRA) and the Obed Wild and Scenic River (WSR), Kentucky and Tennessee

2. Allocations of undiscovered oil and gas resources for Big South Fork National Recreation Area (NRA) and Obed Wild and Scenic River (WSR), Kentucky and Tennessee 


\title{
An Allocation of Undiscovered Oil and Gas Resources to Big South Fork National Recreation Area and Obed Wild and Scenic River, Kentucky and Tennessee
}

\author{
By Christopher J. Schenk, Timothy R. Klett, Ronald R. Charpentier, Troy A. Cook, and Richard M. Pollastro
}

\begin{abstract}
The U.S. Geological Survey (USGS) estimated volumes of undiscovered oil and gas resources that may underlie Big South Fork National Recreation Area and Obed Wild and Scenic River in Kentucky and Tennessee. Applying the results of existing assessments of undiscovered resources from three assessment units in the Appalachian Basin Province and three plays in the Cincinnati Arch Province that include these land parcels, the USGS allocated approximately (1) 16 billion cubic feet of gas, 15 thousand barrels of oil, and 232 thousand barrels of natural gas liquids to Big South Fork National Recreation Area; and (2) 0.5 billion cubic feet of gas, 0.6 thousand barrels of oil, and 10 thousand barrels of natural gas liquids to Obed Wild and Scenic River. These estimated volumes of undiscovered resources represent potential volumes in new undiscovered fields, but do not include potential additions to reserves within existing fields.
\end{abstract}

\section{Introduction}

The Central Energy Team of the U.S. Geological Survey (USGS) was requested by the National Park Service to estimate volumes of undiscovered oil and gas resources that may underlie Big South Fork National Recreation Area (NRA) in Kentucky and Tennessee and Obed Wild and Scenic River (WSR) in Tennessee (fig. 1). Big South Fork NRA is almost entirely within the USGS Appalachian Basin Province, but a small parcel lies within the USGS Cincinnati Arch Province. Obed WSR is entirely within the USGS Appalachian Basin Province. The undiscovered oil and gas resources of the Appalachian Basin Province were assessed most recently by the USGS in 2002 (Milici and others, 2003), and the undiscovered oil and gas resources of the Cincinnati Arch Province were assessed most recently in 1995 (Gautier and others, 1996). These quantitative assessments form the basis for the allocation of resources that may underlie Big South Fork NRA and Obed WSR in the present study.

The USGS defined twenty-six geologic assessment units (AU) within the Appalachian Basin Province. Twenty-two of these were assessed for undiscovered oil and gas resources (Milici and others, 2003), including three AUs that are in the areas of Big South Fork NRA and Obed WSR (table 1). Three plays from the Cincinnati Arch Province assessment (Gautier and others, 1996) included a part of Big South Fork NRA (table 1). For the purpose of our study, we did not reassess the areas of Big South Fork and Obed, but we applied the results of the earlier assessments to allocate undiscovered oil and gas resources for these six AUs or plays. This report summarizes the methodology and results of the allocation process.

\section{Methodology Used for Resource Allocation}

For the six AUs or plays that encompass parts of Big South Fork NRA and Obed WSR, we made the general assumption that the undiscovered resources that had been estimated previously for each of these were evenly distributed across the entire AU or play. This was considered to be the only feasible approach to the resource allocation process. Therefore, we allocated the undiscovered resources to either Big South Fork NRA or Obed WSR according to the percentage of the total land area of each 


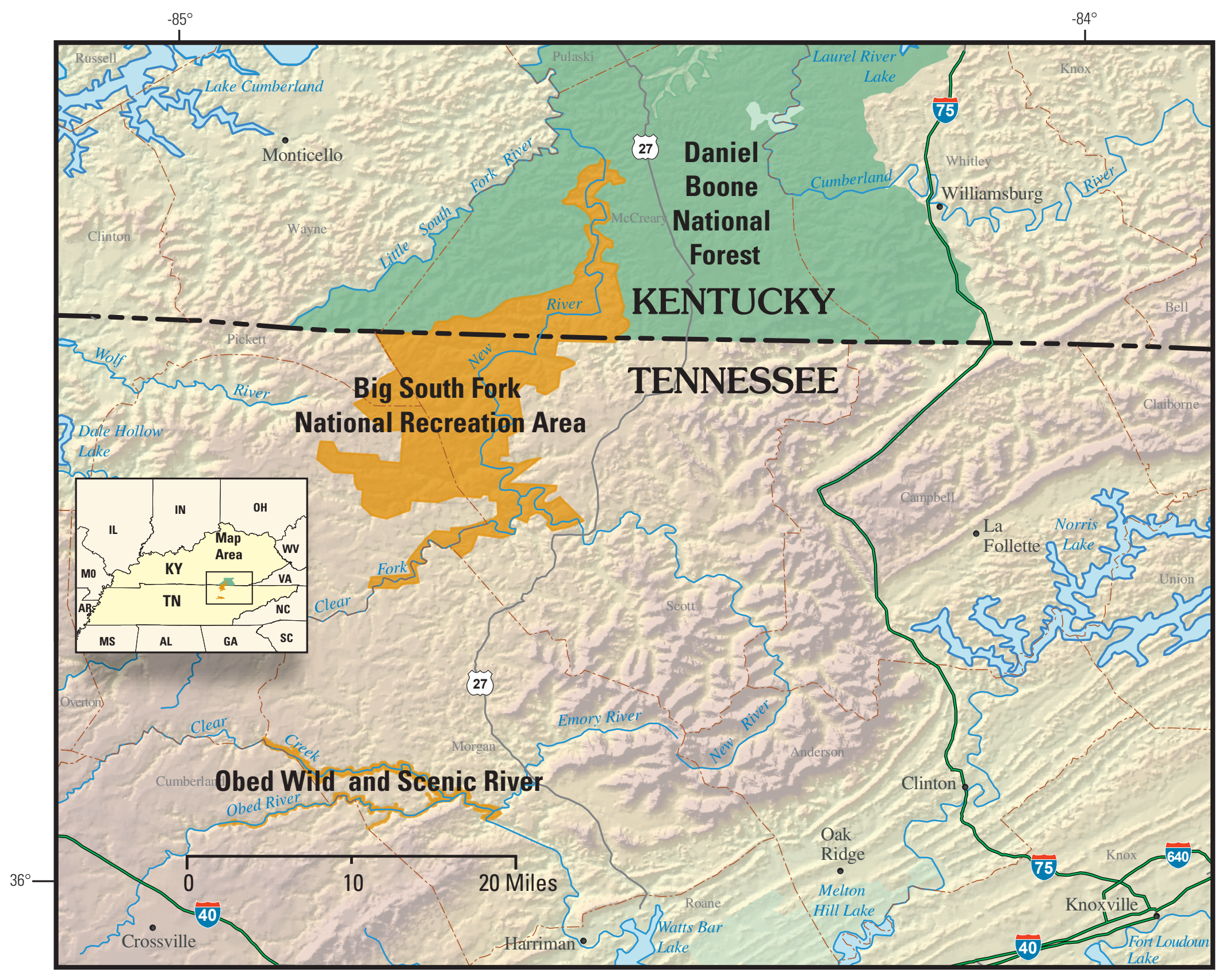

Figure 1. Map showing locations of Big South Fork National Recreation Area and Obed Wild and Scenic River in Kentucky and Tennessee. 
Table 1. Acreages for those parts of assessment units $(A U)$ and plays that lie within the Big South Fork National Recreation Area (NRA) and the Obed Wild and Scenic River (WSR), Kentucky and Tennessee.

[AU names and code numbers from Milici and others (2003); those for plays from Gautier and others (1996)]

\begin{tabular}{|c|c|c|c|c|c|}
\hline \multirow{2}{*}{$\begin{array}{l}\text { Name of AU } \\
\text { or play } \\
\text { (Code no.) }\end{array}$} & \multirow{2}{*}{$\begin{array}{l}\text { Total AU or } \\
\text { play acreage }\end{array}$} & \multicolumn{2}{|c|}{ NRA } & \multicolumn{2}{|c|}{ WSR } \\
\hline & & $\begin{array}{l}\text { Acreage within } \\
\text { AU or play }\end{array}$ & $\begin{array}{l}\text { Percent of } \\
\text { AU or play }\end{array}$ & $\begin{array}{l}\text { Acreage within } \\
\text { AU or play }\end{array}$ & $\begin{array}{l}\text { Percent of } \\
\text { AU or play }\end{array}$ \\
\hline \multicolumn{6}{|c|}{ Appalachian Basin Province Assessment Units } \\
\hline $\begin{array}{l}\text { Rome Trough } \\
(50670101)\end{array}$ & $39,594,309$ & 124,264 & 0.314 & - & - \\
\hline $\begin{array}{l}\text { Cambrian Limestone } \\
(50670403)\end{array}$ & $22,702,637$ & 124,264 & 0.547 & 5,324 & 0.023 \\
\hline $\begin{array}{l}\text { Northwest Ohio Shale } \\
(50670462)\end{array}$ & $29,337,139$ & 124,264 & 0.423 & 5,324 & 0.018 \\
\hline \multicolumn{6}{|c|}{ Cincinnati Arch Province Plays } \\
\hline $\begin{array}{l}\text { Cambrian and Lower } \\
\text { Ordovician Carbonate } \\
(6601)\end{array}$ & $41,585,845$ & 3,720 & 0.0089 & - & - \\
\hline $\begin{array}{l}\text { Middle and Upper } \\
\text { Ordovician Carbonate } \\
(6602)\end{array}$ & $39,457,623$ & 3,720 & 0.0094 & - & - \\
\hline $\begin{array}{l}\text { Devonian Black } \\
\text { Gas Shale } \\
(6604)\end{array}$ & $8,515,786$ & 3,720 & 0.044 & - & - \\
\hline
\end{tabular}

AU or play that lay within one or another of these tracts (table 1). For example, if Big South Fork NRA represented one percent of the land area of a given AU, we allocated one percent of the mean undiscovered resource to Big South Fork NRA from the USGS assessment of that AU; this procedure was followed for each AU or play. We then aggregated the allocations into a total volume of undiscovered resources for Big South Fork NRA and Obed WSR. The allocated potential resources, however, are only in terms of undiscovered fields. We did not estimate either the number of undiscovered fields or the number of wells that may be necessary to recover these potential, undiscovered resources.

\section{Results}

As discussed above, the allocation procedure provided estimates of the total volumes of undiscovered oil and gas resource that may underlie Big South Fork NRA and Obed WSR (table 2). The resulting estimates are: (1) 16 billion cubic feet of gas (BCFG), 15 thousand barrels of oil (MBO), and 232 thousand barrels of natural gas liquids (MBNGL) for the Big South Fork NRA; and (2) 0.5 BCFG, 0.6 MBO, and about 10 MBNGL for the Obed WSR.

Several oil and gas fields exist partly or wholly within the boundary of Big South Fork NRA (fig. 2) and within the boundary of Obed WSR (fig. 3). Field boundaries as shown in figures 1 and 2 are not state-defined boundaries, but are areas we outlined within which oil and gas wells were assigned to a specific field. Undiscovered resources allocated to Big South Fork and Obed would, by definition, be located outside existing fields. 
Table 2. Allocations of undiscovered oil and gas resources for Big South Fork National Recreation Area (NRA) and Obed Wild and Scenic River (WSR), Kentucky and Tennessee.

[Assessment Unit (AU) names and code numbers from Milici and others (2003); those for plays from Gautier and others (1996). Resource volumes are stated as mean values. Abbreviations: MBO, thousand barrels of oil; BCF, billion cubic feet of gas; MBNGL, thousand barrels of natural gas liquids]

\begin{tabular}{|c|c|c|c|c|c|c|}
\hline \multirow{2}{*}{$\begin{array}{l}\text { Name of AU } \\
\text { or play } \\
\text { (Code no.) }\end{array}$} & \multicolumn{3}{|c|}{ NRA } & \multicolumn{3}{|c|}{ WSR } \\
\hline & $\begin{array}{c}\text { Oil } \\
\text { (MMBO) }\end{array}$ & $\begin{array}{l}\text { Gas } \\
\text { (BCF) }\end{array}$ & $\begin{array}{l}\text { Liquids } \\
\text { (MBNGL) }\end{array}$ & $\begin{array}{c}\text { Oil } \\
\text { (MMBO) }\end{array}$ & $\begin{array}{l}\text { Gas } \\
\text { (BCF) }\end{array}$ & $\begin{array}{l}\text { Liquids } \\
\text { (MBNGL) }\end{array}$ \\
\hline \multicolumn{7}{|c|}{ Appalachian Basin Province Assessment Units } \\
\hline $\begin{array}{l}\text { Rome Trough } \\
(50670101)\end{array}$ & - & 1.9 & - & - & - & - \\
\hline $\begin{array}{l}\text { Cambrian Limestone } \\
(50670403)\end{array}$ & 13.4 & 0.7 & 7.6 & 0.6 & - & 0.3 \\
\hline $\begin{array}{l}\text { Northwest Ohio Shale } \\
(50670462)\end{array}$ & - & 11.2 & 224.5 & - & 0.5 & 9.6 \\
\hline \multicolumn{7}{|c|}{ Cincinnati Arch Province Plays } \\
\hline $\begin{array}{l}\text { Cambrian and Lower } \\
\text { Ordovician Carbonate } \\
(6601)\end{array}$ & 0.7 & 0.7 & - & - & - & - \\
\hline $\begin{array}{l}\text { Middle and Upper } \\
\text { Ordovician Carbonate } \\
(6602)\end{array}$ & 0.8 & 0.8 & - & - & - & - \\
\hline $\begin{array}{l}\text { Devonian Black } \\
\text { Gas Shale } \\
(6604)\end{array}$ & - & 0.6 & - & - & - & - \\
\hline
\end{tabular}




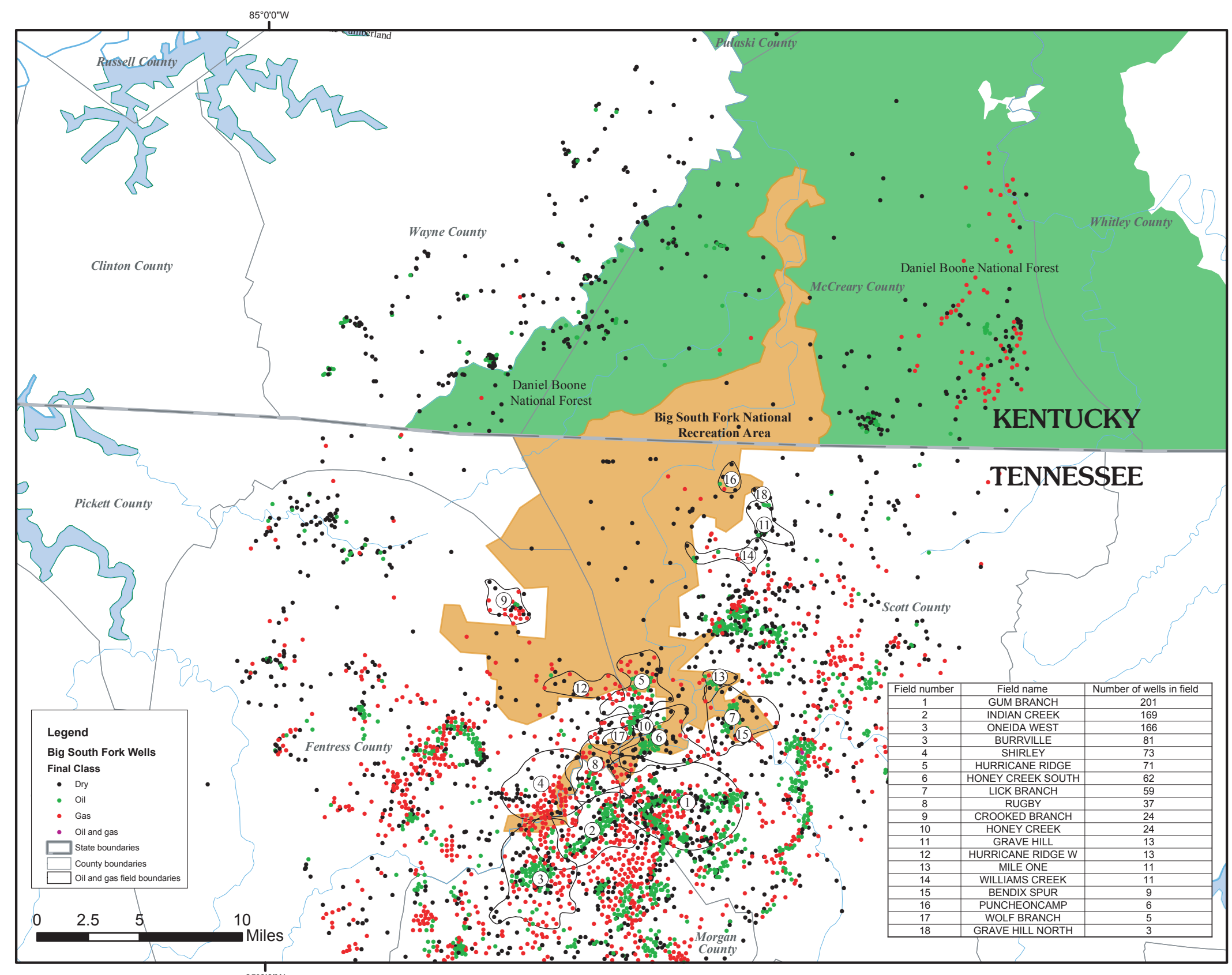

$85^{\circ} 0^{\prime} 0 \mathrm{WW}$

Figure 2. Map showing oil and gas wells and selected oil and gas fields in and around Big South Fork National Recreation Area, Kentucky and Tennessee. 


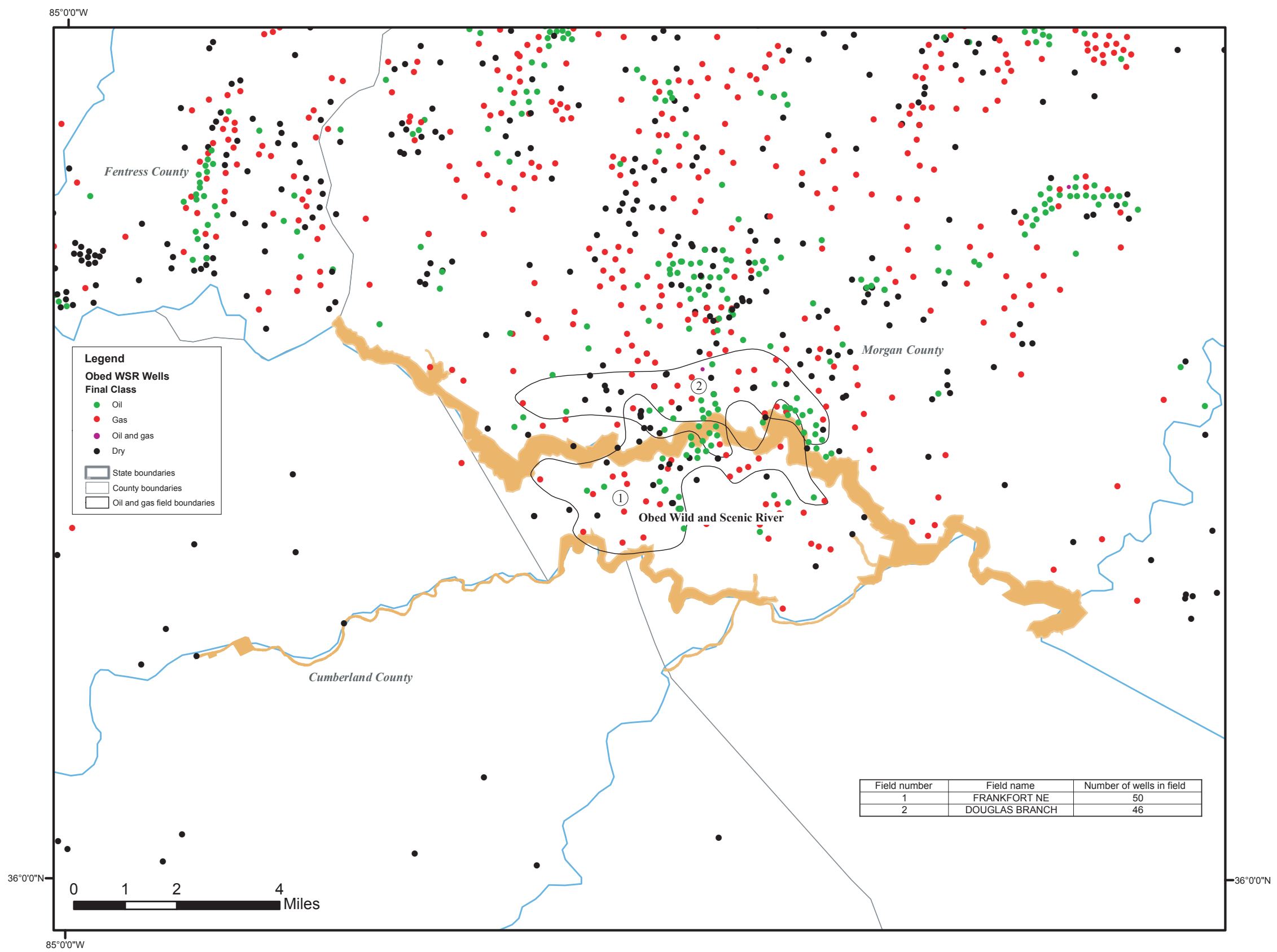

Figure 3. Map showing oil and gas wells and selected oil and gas fields in and around Obed Wild and Scenic River, Tennessee 


\section{References}

Gautier, D.L., Dolton. G.L., Takahashi, K.I., and Varnes, K.L., eds., 1996, 1995 National assessment of United States oil and gas resources—results, methodology, and supporting data: U.S. Geological Survey Digital Data Series DDS-30, Release 2, one CD-ROM.

Milici, R.C., Ryder, R.T., Swezey, C.S., Charpentier, R.R., Cook, T.A., Crovelli, R.A., Klett, T.R., Pollastro, R.M., and Schenk, C.J., 2003, Assessment of undiscovered oil and gas resources of the Appalachian Basin Province, 2002: U.S. Geological Survey Fact Sheet FS-009-03. 